\title{
Highly stable microtubular cells for portable solid oxide fuel cell applications
}

\author{
H. Monzón and M. A. Laguna-Bercero*
}

Instituto de Ciencia de Materiales de Aragón, U. Zaragoza-CSIC, C/ María de Luna 3, E-50.018

Zaragoza, Spain

*malaguna@unizar.es

\begin{abstract}
In this work, extruded support tubes based on Nickel Oxide-YSZ (yttria stabilized-zirconia) were manufactured by Powder Extrusion Moulding (PEM). An YSZ layer is then deposited by dip coating as the electrolyte and subsequently, standard $\mathrm{La}_{0.8} \mathrm{Sr}_{0.2} \mathrm{MnO}_{3-\delta}(\mathrm{LSM}) / \mathrm{YSZ}$ composites were deposited by dip coating as oxygen electrodes. Microstructure of the anode support was optimized in order to achieve the maximum fuel utilization and as a consequence, a high performance of the cells. Experiments as a function of the fuel composition showed power densities above $500 \mathrm{mWcm}^{-2}$ at $800{ }^{\circ} \mathrm{C}$ at $0.7 \mathrm{~V}$, with high fuel utilization ( 75\%). Long-term durability studies were also performed for a period above 1000 hours. The experiment was conducted at $800{ }^{\circ} \mathrm{C}$ using pure humidified hydrogen at a fixed voltage of $0.8 \mathrm{~V}$. It was observed that the current density of the cell is significantly evolving during the initial period of about 100 hours, as a consequence of reconditioning of nickel particles at the anode support. Once the system is stabilized, no degradation was observed up to 1000 hours under operating conditions, obtaining current densities in the range of $400 \mathrm{mAcm}^{-2}$ at $0.8 \mathrm{~V}$ and $800{ }^{\circ} \mathrm{C}$.
\end{abstract}

Keywords: Nickel; yttria stabilized zirconia; SOFC; microtubular; durability; fuel utilization 


\section{Introduction}

Solid Oxide Fuel Cells (SOFCs) are devices able to transform chemical energy into work with high efficiency and low, or none, emission of pollutants [1]. They can use hydrogen as fuel, in addition to hydrocarbons. Moreover, they can be used to transform energy into hydrogen, which can be stored to be later used. Regarding their geometry, microtubular SOFCs (mSOFCs) present higher energetic density, better resistance to thermal stresses and smaller starting times than conventional planar stacks $[2,3]$. Thus, they are suitable for portable applications in the sub $\mathrm{kW}$ energy range. Microtubular SOFC fabrication is a demanding process, as several ceramic layers of different compositions and microstructures need to be matched in a final device. One of the key parameters is to achieve strong interfaces between the different components and thus reducing polarization losses of the cells. For that purpose, different fabrication methods for the tubular supports were reported, such as cold isostatic pressing [4,5], powder extrusion moulding (PEM) $[6,7,8]$, powder injection moulding (PIM) [9], gel-casting $[10,11]$, slip-casting $[12,13]$ or the immersion-induced inversion method $[14,15]$. Currently, the state of the art configuration for microtubular cells is the use on anode supported cells, and the most used composition is nickelYSZ [2,3]. However, probably their main limitation is achieving high fuel utilizations, as the tubular geometry does not allow an easy regulation of gases along the length of the tube [16]. Optimization of the microstructure of the support is then one of the key parameters during fabrication, as it is required good electronic conduction along the thickness of the tubular support maintain an adequate fuel transport along the channels, in order to optimize fuel utilization (FU), being this is one of the major concerns of microtubular SOFCs. In fact, higher fuel utilization was recently reported for microtubular SOFCs by optimizing the porosity of the Ni-YSZ supports. Sumi 
et al. [17] studied the use of graphite and acrylic resin as pore forms. They confirmed the importance of the porosity distribution, as the Ni-YSZ microtube using graphite as pore former had a relatively uniform distribution of micropores, and showed higher fuel utilization (93\%) in spite of low porosity in the anode. The microtube using acrylic resin as pore former, presenting higher porosity, showed a maximum fuel utilization of $72 \%$. Although these high fuel utilizations are feasible, it is known that higher fuel utilizations lead to strong degradations associated to nickel oxidation/reduction processes. For example, a degradation rate of $8 \%$ per 1000 hours has been observed for cells operated over more than $1500 \mathrm{~h}$ under fuel utilizations of $40 \%$ [18].

Durability is then a crucial aspect for SOFC applications with a strong dependence on cell processing parameters and also on the operation conditions. In the case of anode-supported cells, one of the major concerns is the dimensional changes associated to coarsening of nickel particles and redox cycling during cell operation $[19,20]$. Other problems related to mSOFCs are the resistance to severe and rapid thermal cycles [21], carbon deposition in the nickel catalyser when using hydrocarbons [22], as well as current collection issues related to the tubular geometry [23].

The objective of the present work is the optimization of mSOFC cells in terms of fuel utilization and long-term durability. Extruded support tubes based on Nickel Oxide-YSZ (yttria stabilizedzirconia) were recently manufactured by Powder Extrusion Moulding (PEM) [7]. Feedstock composition and extruding parameters were adjusted to obtain highly reproducible tubular green bodies, followed by deposition of the electrolyte (YSZ) and cathode (Lanthanum Strontium Manganite LSM/ YSZ) [24]. These cells showed typical power densities around $0.5 \mathrm{Wcm}^{-2}$ at ca. $0.6 \mathrm{~V}$ and $800^{\circ} \mathrm{C}$. 


\section{Experimental}

NiO-YSZ tubular anode supports were produced by PEM. The powder composition was based on NiO (GNO grade F, Hart Materials, median particle size $D_{50}=0.7 \mu \mathrm{m}$ ), YSZ (TZ-8YS, Tosoh Corporation, $D_{50}=0.9 \mu \mathrm{m}$ ) and corn starch (Maizena, $D_{50}=10.4 \mu \mathrm{m}$ ) as pore former to increase the porosity of anode supports. Final composition of the anode support was adjusted to a Ni-YSZ ratio of 50:50 (\% in volume of solid phase), and porosities in the range of 50\%. Additional details about the extrusion process, as well as the debinding process to eliminate the organic load, are shown in reference [7] and [24]. Subsequently YSZ was deposited as the electrolyte and cosintered at $1500{ }^{\circ} \mathrm{C}$ during 2 hours. Finally, LSM A-site deficient manganite (La0.8 $\left.\mathrm{Sr}_{0.2}\right)_{0.98} \mathrm{MnO}_{3}$ (Fuelcell Materials) was used as the oxygen electrode. A composite of LSM/YSZ (50/50 wt\%) was used to deposit a functional layer on the electrolyte surface and a composite of LSM/YSZ (80/20 wt\%) for the current collector layer. Final dimensions of the microtubular cells are: $6 \mathrm{~mm}$ in length, $3.2 \mathrm{~mm}$ outer diameter, $2 \mathrm{~mm}$ inner diameter, $20 \mu \mathrm{m}$ YSZ electrolyte, $15 \mu \mathrm{m}$ LSM/YSZ functional layer, $15 \mu \mathrm{m}$ LSM/YSZ current collection layer, and $1 \mathrm{~cm}^{2}$ of oxygen electrode active area.

For the electrochemical studies, microtubular cells were sealed into alumina tubes using ceramic sealing and then introduced in a three-zone tubular furnace with a homogeneous hot zone of 5 $\mathrm{cm}$ in length. Additional information about the placement of the electrical contacts and the experimental set up can be found in references [25] and [26]. Electrochemical impedance spectroscopy (EIS), potentiodynamic and chronoamperostatic studies were performed using a VSP Potentiostat/Galvanostat (Princeton Applied Research, Oak Ridge, US). EIS experiments were performed under OCV conditions applying a sinusoidal amplitude of $20 \mathrm{mV}$. Slow 
potentiodynamic experiments were performed from OCV down to $0.5 \mathrm{~V}$ at $0.25 \mathrm{mAs}^{-1}$. In order to study the effect of fuel utilization on the performance of the microtubular cells, different fuel conditions varying from 100 to $5 \mathrm{~cm}^{3} \mathrm{~min}^{-1}$ were studied, using pure hydrogen humidified at room temperature (RT): $97 \% \mathrm{H}_{2}-3 \% \mathrm{H}_{2} \mathrm{O}$ at $800{ }^{\circ} \mathrm{C}$. Long-term durability studies were also performed for a period above 1000 hours. The experiment was carried out at $800^{\circ} \mathrm{C}$ and a fuel composition of $97 \% \mathrm{H}_{2}-3 \% \mathrm{H}_{2} \mathrm{O}$. Chronoamperometric studies were performed at a fixed voltage of $0.8 \mathrm{~V}$ while current density was monitored. Periodically, EIS and Current density - voltage (j-V) curves were performed.

Finally, the samples were observed in a Merlin FE-SEM (Carl Zeiss) in order to study their possible microstructure evolution. Samples were cut, infiltrated with epoxy resin under vacuum, ground and polished. Observations were made at low accelerating voltages in order to obtain contrast between the nickel and YSZ phases using an EsB (Energy selective Backscattered) detector.

\section{Results and discussion}

\subsection{Electrochemical characterization}

\subsubsection{Effect of fuel utilization}

A microtubular Ni-YSZ/YSZ/LSM-YSZ cell was tested varying the flux of hydrogen as fuel. Current density - voltage $(j-V)$ curves are shown in figure 1 (a). As observed, when using fuel fluxes above $10 \mathrm{~cm}^{3} \mathrm{~min}^{-1}$ there is almost no variation in the internal resistance of the cell. However, for 10 $\mathrm{cm}^{3} \mathrm{~min}^{-1}$, typical fuel utilization losses are observed at high current densities. Fuel utilization for 
each condition was calculated, as observed in figure 1 (b). As clearly observed, diffusion resistance losses are observed at a fuel utilization of about 70\%, as a consequence of the optimized microstructure of anode supports. The obtained values are very competitive, as a fuel utilization of $58 \%$ is feasible operating at $0.7 \mathrm{~V}$. For comparison purposes, $\mathrm{MHI}$ (Mitsubishi Heavy Industries Ltd., Japan) showed fuel utilizations of $50 \%$ at $0.7 \mathrm{~V}$ using anode supported mSOFC stacks [27], and Lee et al. [28] also showed similar values (45\%) .

In order to identify the contribution of fuel utilization to the resistance of the cells, EIS experiments were also performed (figure 2). The equivalent circuit shown in the inset of the figure was used to fit experimental data, in order to analyze the three different observed processes. Their typical summit frequencies and resistance values are: R1 - high frequency (HF) contribution at $1.6-16 \mathrm{kHz}$ and nearly constant resistances of $\sim 0.35 \Omega \mathrm{cm}^{2} ; \mathrm{R} 2$ - medium frequency (MF) at 20$27 \mathrm{~Hz}$ and nearly constant resistances of $\sim 0.3 \Omega \mathrm{cm}^{2}$; and R3 - low frequency (LF) at 0.2-4 Hz with resistances varying from $0.9 \Omega \mathrm{cm}^{2}$ (low flux of $5 \mathrm{~cm}^{3} \mathrm{~min}^{-1}$ ) to $0.2 \Omega \mathrm{cm}^{2}$ (high flux of $50 \mathrm{~cm}^{3} \mathrm{~min}^{-}$ $\left.{ }^{1}\right)$. The observed variation of this resistance value at OCV conditions is large, especially when reducing the flux from 10 to $5 \mathrm{~cm}^{3} \mathrm{~min}^{-1}$. Experiments under current load (200 $\mathrm{mA}$ ) were also performed (not shown). A similar trend was observed, although this effect is more noticeable under OCV conditions. Total polarization resistances in the range of $0.7-0.8 \Omega \mathrm{cm}^{2}$ were obtained under current low, even using a low hydrogen flux of $5 \mathrm{~cm}^{3} \mathrm{~min}^{-1}$. In addition, as shown in figure 2 , the contribution at low frequencies (LF) is increasing when decreasing the hydrogen flux while the medium frequency (MF) and the high frequency (HF) peaks remain almost unaltered. Additionally, it is clearly observed that the characteristic frequency of the LF contribution is decreasing when decreasing the flux. It is then concluded that the LF process corresponds to a 
diffusive limitation, known as gas conversion impedance. This evidence was also confirmed by the lineal dependence of the inverse of the flux vs. the LF polarization resistance, as reported by Momma et al. [29]. As the HF and MF processes remain almost unaltered against both $\mathrm{pH}_{2}$ (hydrogen partial pressure) and flux of hydrogen, it is reasonable to assume that both contributions correspond to the LSM-YSZ oxygen electrode. Based on the extensive literature, the HF contribution was assigned to resistances at the interface between the electrolyte and the electrode, and the MF contribution was assigned to charge transfer and dissociative oxygen adsorption [30,31,32].

Although the performance and FU of these microtubular cells meet the requirements for portable applications, additional strategies such as the use of additional pore formers (graphite or polymethyl methacrylate) and the implementation of anode functional layers will be considered in forthcoming studies.

\subsubsection{Durability studies}

As previously described, one of the major concerns of anode supported SOFCs is their degradation associated to nickel coarsening during long term operation $[33,34]$. In order to study this effect in our microtubular cells, a chronoamperometric experiment was performed for a period of about 1000 hours at $800{ }^{\circ} \mathrm{C}, 0.8 \mathrm{~V}$ and $5 \mathrm{~cm}^{3} \mathrm{~min}^{-1}$ of $97 \% \mathrm{H}_{2}-3 \% \mathrm{H}_{2} \mathrm{O}$ as fuel composition. Although higher FUs will be required for practical applications as for of planar geometries, fuel utilization of $\sim 40 \%$ was selected for the chronoamperometric experiment as this is the current state of the

art in microtubular devices for long term experiments $[16,18]$. In this experiment, as observed in 
the chronoamperometry of figure 3 , there is an initial non-stationary period during the first 20 hours, associated to reaccommodation of nickel particles after NiO reduction. This effect was previously observed for shorter durability studies [35], where a complete EIS and microstructural study was performed. After this period, the system is about constant obtaining current densities of $\sim 400 \mathrm{mAcm}^{2}$. Small oscillations during these experiments were attributed to room temperature (RT) differences between day and night. It is very remarkable that almost zero degradation was obtained after the initial stabilization of the cell. This result is consistent with other durability studies found in the literature for microtubular cells $[6,25]$. Those results confirm that durability of microtubular cells is lower than for planar cells, where typical degradation rates of above $1 \%$ per $1000 \mathrm{~h}^{-1}$ are usually found [36]. The advantage of mSOFC configuration is that low temperature sealing can be used and, as a consequence, lower diffusion of species into the cells is expected, possibly being the reason for the enhanced durability of mSOFCs.

$j$-V characterization was also performed during the chronoamperometric studies, as shown in figure 4 (a). During this period, although small differences associated to RT changes are observed, there is no degradation in terms of fuel cell performance for a period above 1000 hours under operation conditions. Similar findings were observed from EIS experiments collected after the initial stabilization period and after the complete chronoamperometry (figure 4 (b)). It should be pointed out that those experiments where conducted at OCV using a sinusoidal amplitude of 20 $\mathrm{mV}$. Under those conditions, as the system is changing from anodic to cathodic polarization, small differences can be observed at the EIS spectra specially at low frequencies (as observed in the figure). It can be concluded that the small differences were associated to instability of the system and/or small temperature changes during the experiment, and clearly there is no significant 
variation in the ASR values when comparing the initial and final state. When EIS measurements at $92 \mathrm{~h}$ and $1038 \mathrm{~h}$ are directly compared, it is then established that there is almost no variation for the cell between the period of $\sim 100$ and $~ 1000$ hours.

\subsection{Microstructural characterization}

SEM studies were performed in cells operated under different conditions in order to understand the possible degradation mechanisms. Figure 5 shows the typical microstructure of the anode, for cells just after NiO reduction (initial state) and after operation ( 100 and 1000 hours). Nickel coarsening during operation has been extensively studied in the literature $[34,37,38]$. In concordance with previous findings [34], as also observed during the initial hours of the chronoamperometry shown in figure 3 , there is an initial small degradation as a consequence of the coarsening of the smallest nickel particles. However, it is very remarkable from this experiment that despite of the further significant nickel particles growth, there is no degradation in terms of fuel cell performance. It seems that after $\sim 1000$ hours there is still enough porosity in the anode support for an easy gas flow along the tubes. In addition, although nickel coarsening is clearly visible during long-term operation, there is no depletion of nickel at the anode/electrolyte interphase assuring an efficient exchange of current needed for hydrogen dissociation. In addition, nickel remains as a percolating phase after 1000 hours at the anode/electrolyte interphase. One of the common causes of mSOFCs degradation is the loss of current collection ascribed to the nickel oxidation and agglomeration [18], which we do not observe in our case. It is reasonable to assume that in our cells, LSM-YSZ cathode is the limiting electrode, as despite of those reported 
microstructural changes on the Ni-YSZ anode side there is no degradation in terms of current density.

After those experiments, it is concluded that after the initial conditioning of the cell, and for a period of above 1000 hours under operation conditions, it was not possible no quantify any degradation [39]. Those results confirm that the studied cells are suitable to be integrated for mSOFC portable devices.

\section{Conclusions}

Microtubular anode supported NiO-YSZ/YSZ/LSM-YSZ cells were characterized in terms of fuel utilization and long-term durability. In despite of their thick wall-thickness ( 600 $\mu \mathrm{m})$, they are able to achieve fuel utilizations of $58 \%$ operating at $0.7 \mathrm{~V}$. At least, three major processes were identified by EIS studies, occurring at LF (gas conversion impedance at the anode support), MF (charge transfer and dissociative oxygen adsorption at the oxygen electrode) and HF (resistances at the interface between the electrolyte and the oxygen electrode).

A chronoamperometry study under current load revealed that there is an initial non-stationary period during the first 20 hours, associated to re-accommodation of nickel particles after $\mathrm{NiO}$ reduction. After this period, there was no degradation observed from $\mathrm{j}-\mathrm{V}$ and EIS studies, and the system is about constant obtaining current densities of $\sim 400 \mathrm{mAcm}^{2}$. Although evident nickel particles growth, as observed by SEM experiments after operation, there is no degradation in terms of fuel cell performance for a period above 1000 hours. Those findings confirm that these cells achieve the requirements for their integration into mSOFC portable devices. 


\section{Acknowledgments}

Authors would like to thank Prof. A. Varez group for assistance with PEM fabrication of the mSOFC supports. The project MAT2015-68078-R, financed by the Spanish Government (Ministerio de Economía y Competitividad) and the Feder program of the European Union, is also acknowledged.

Finally, authors acknowledge the use of Servicio General de Apoyo a la Investigación-SAI, Universidad de Zaragoza. 


\section{Figure captions}

Figure 1. (a) Fuel utilization as a function of the operation voltage for different fluxes of humidified hydrogen measured at $800^{\circ} \mathrm{C}$; (b) Fuel utilization as a function of the power density for different fluxes of humidified hydrogen measured at $800{ }^{\circ} \mathrm{C}$.

Figure 2. EIS experiments (Bode diagrams) for different fluxes of humidified hydrogen measured at OCV and $800{ }^{\circ} \mathrm{C}$.

Figure 3. Chronoamperometric study performed at $800{ }^{\circ} \mathrm{C}$ and $0.7 \mathrm{~V}$ using pure humidified hydrogen as fuel.

Figure 4. (a) Current density vs. voltage performed at different stages during the chronoamperometric study; (b) EIS experiments (Nyquist diagrams) performed at different stages during the chronoamperometric study.

Figure 5. Transverse-cross polished sections (FE-SEM images) showing the microstructure of the Ni-YSZ support at different stages of the chronoamperometric study. In all images, metallic nickel corresponds to the brighter phase, YSZ to the intermediate phase, and pores to the darker phase. The two images at higher magnification were collected using an InLens detector in order to distinguish between percolating and non-percolating nickel [40]. 
Figure 1 (a).

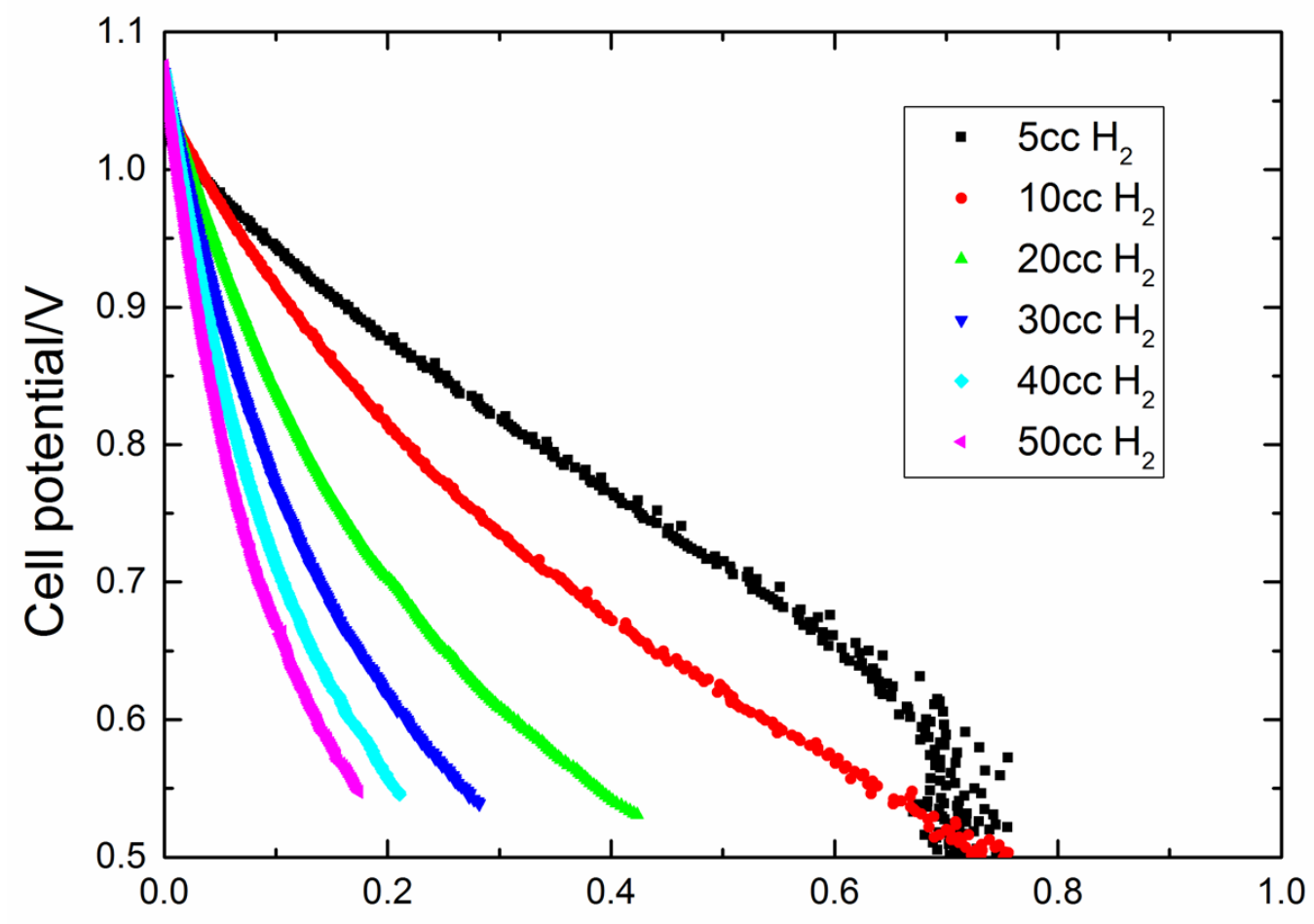

Fuel utilization 
Figure 1 (b).

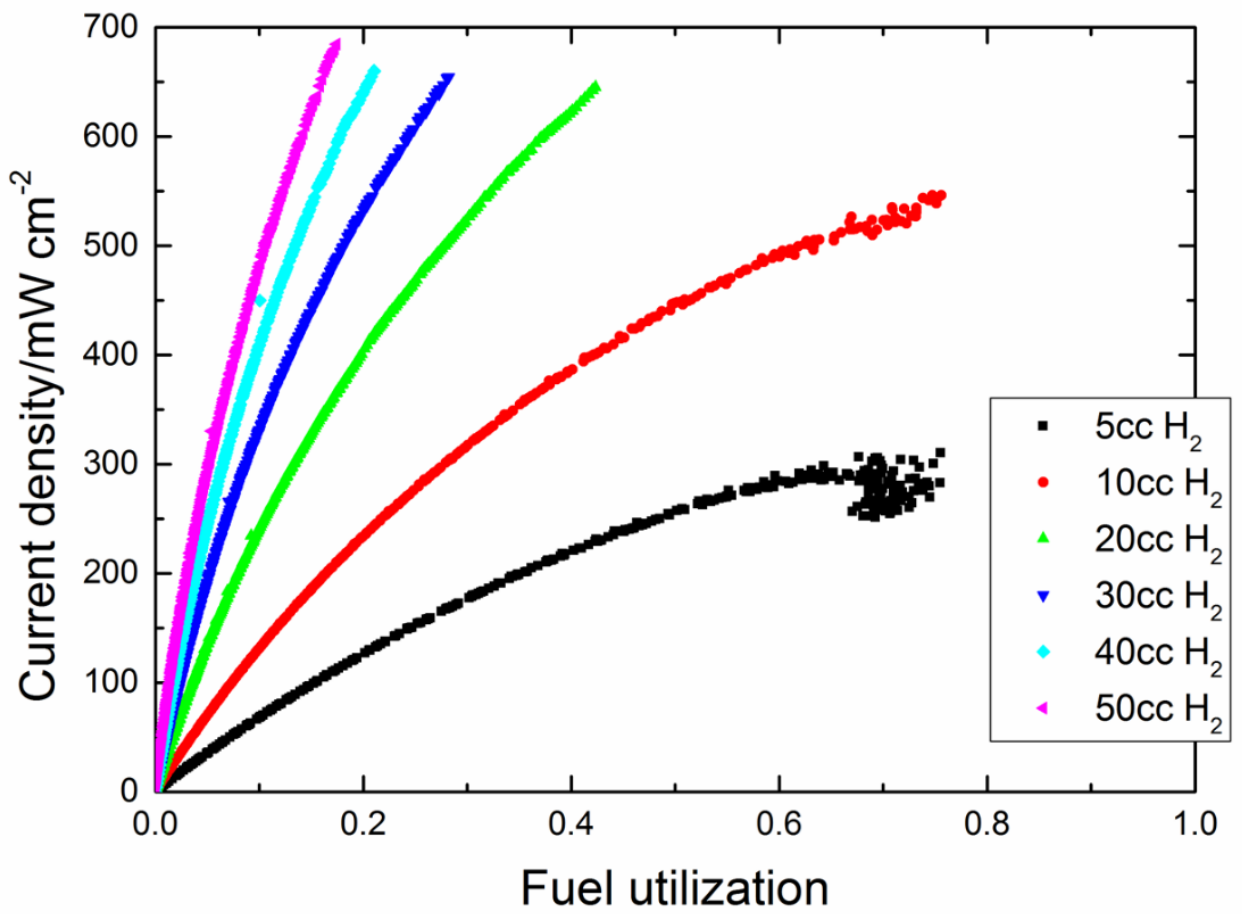


Figure 2.
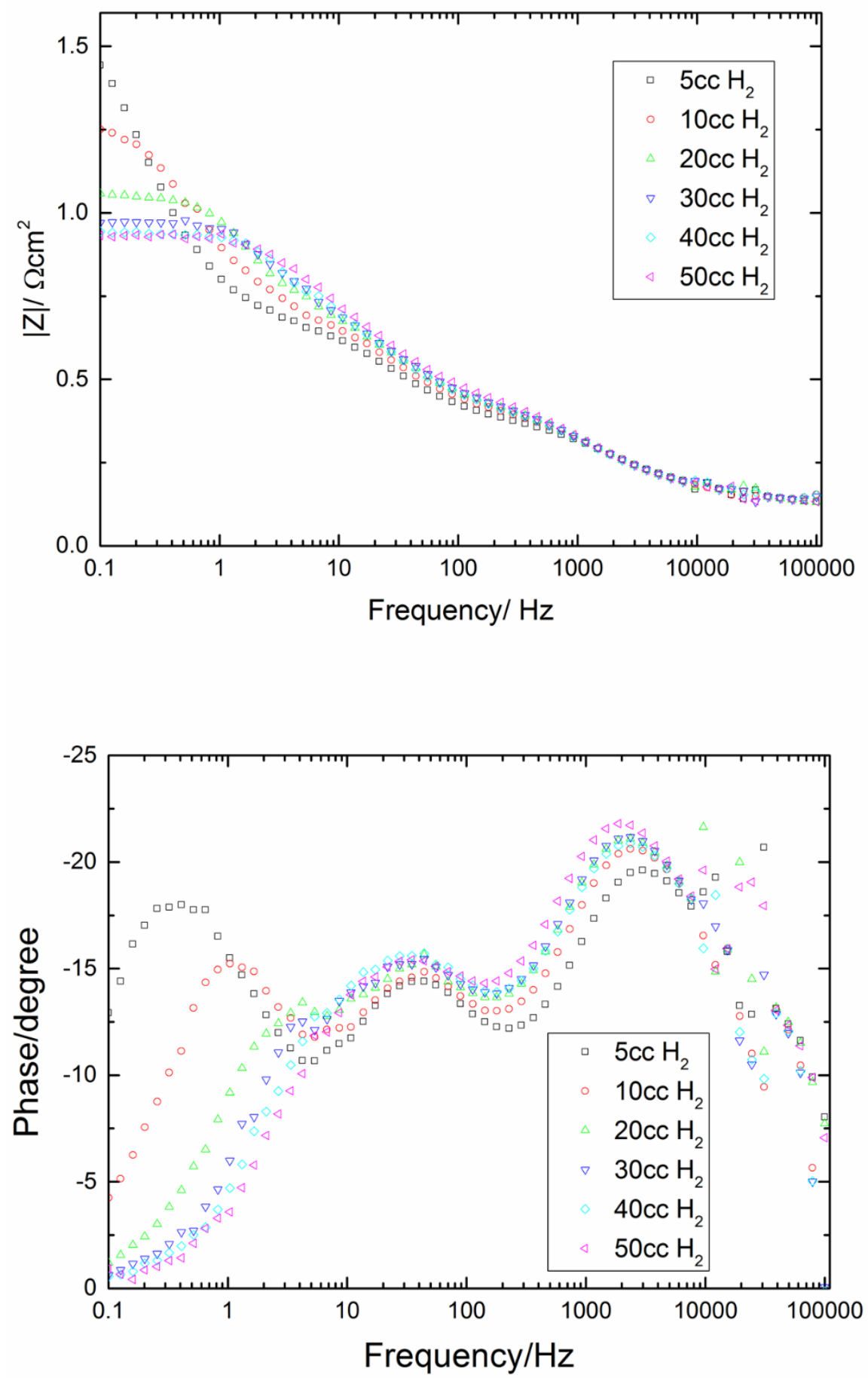
Figure 3.

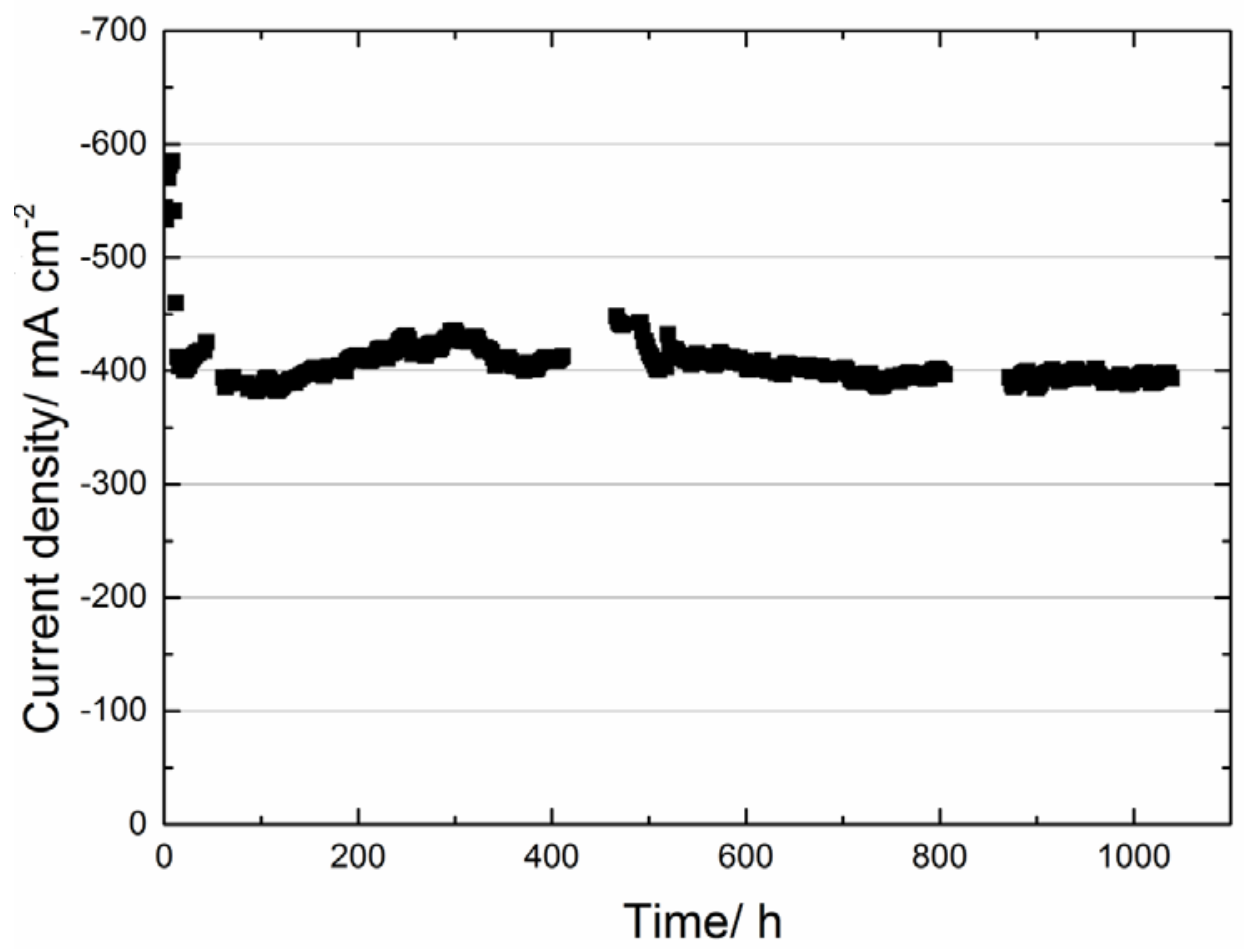


Figure 4 (a).

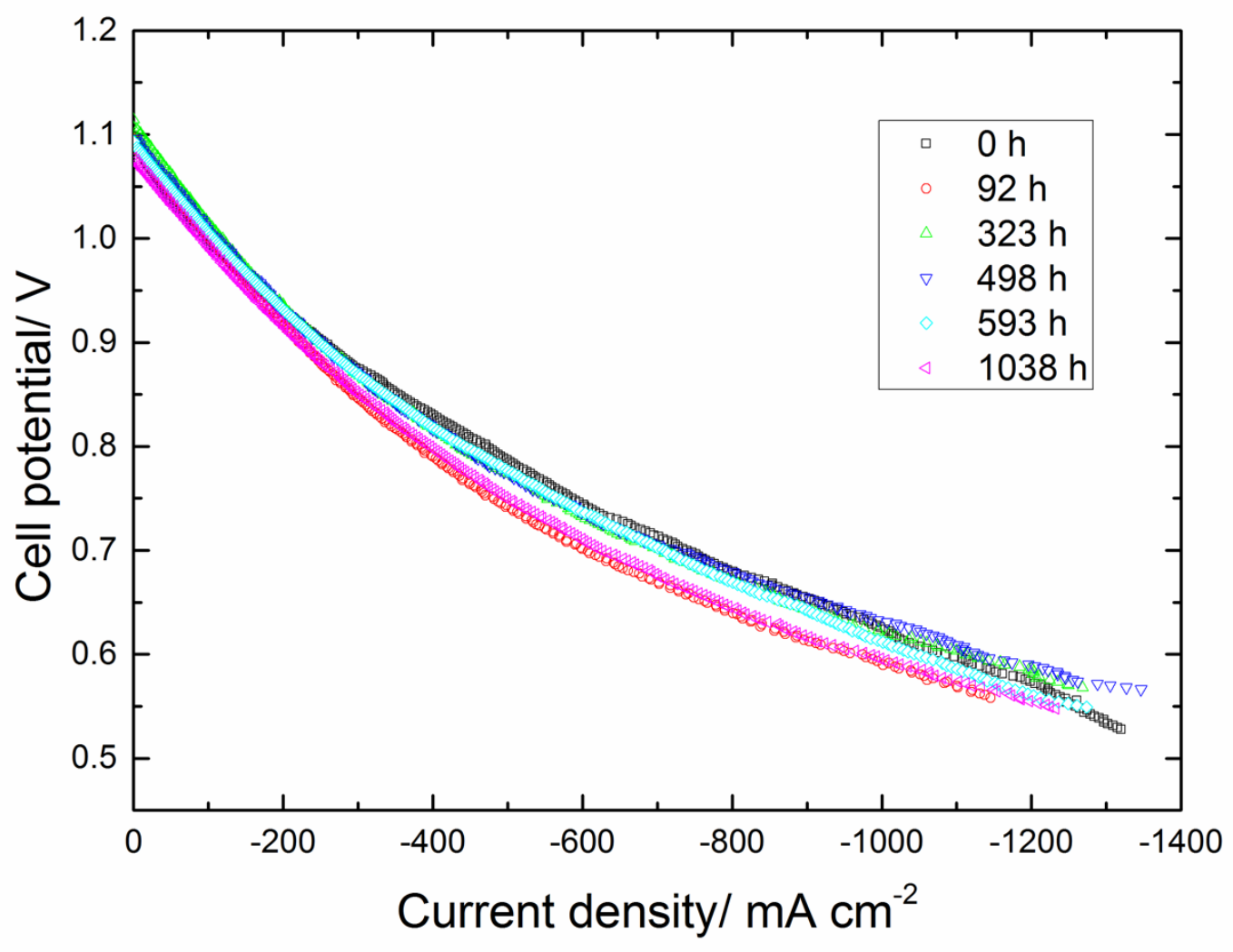


Figure 4 (b).

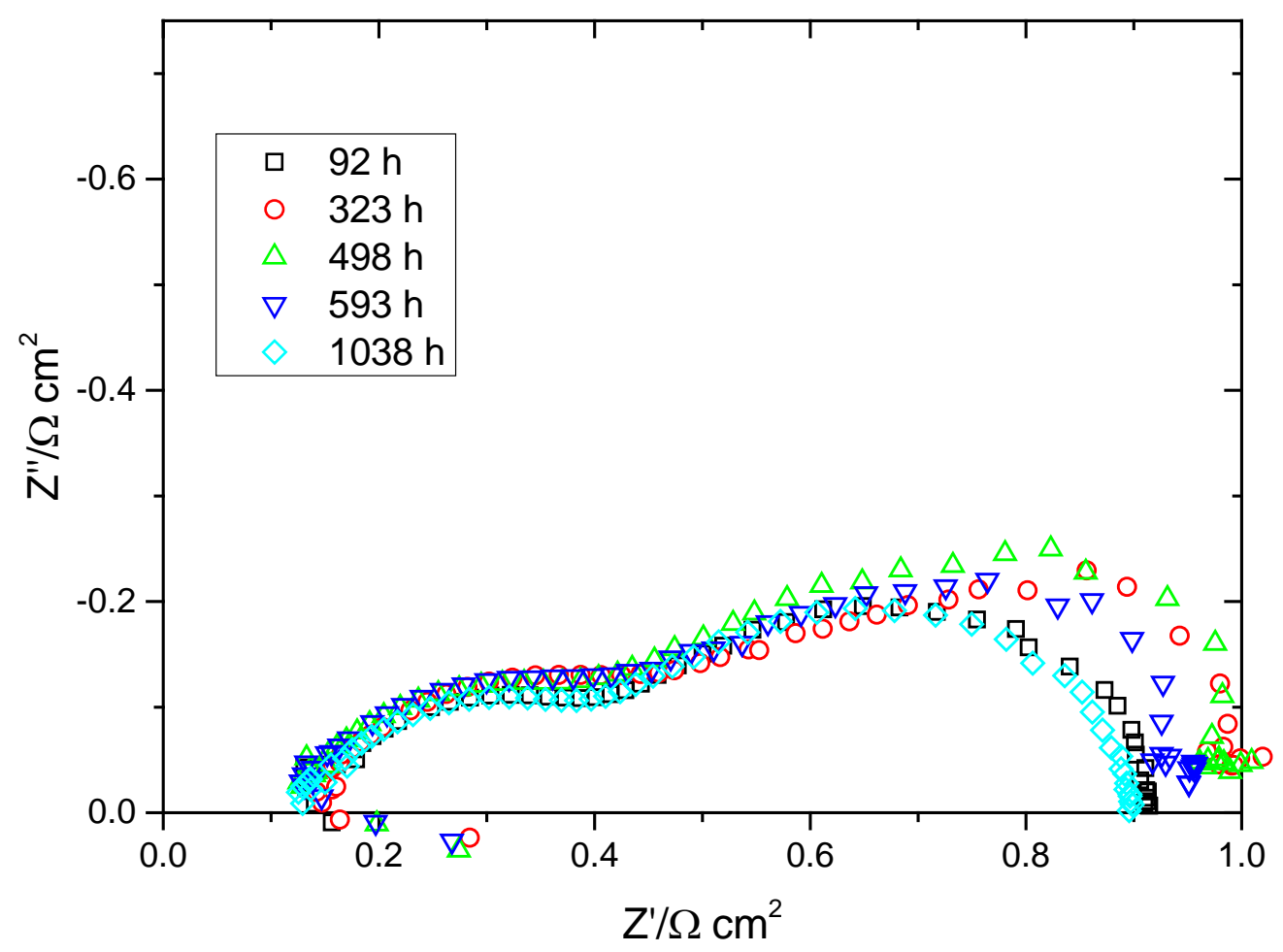


Figure 5.
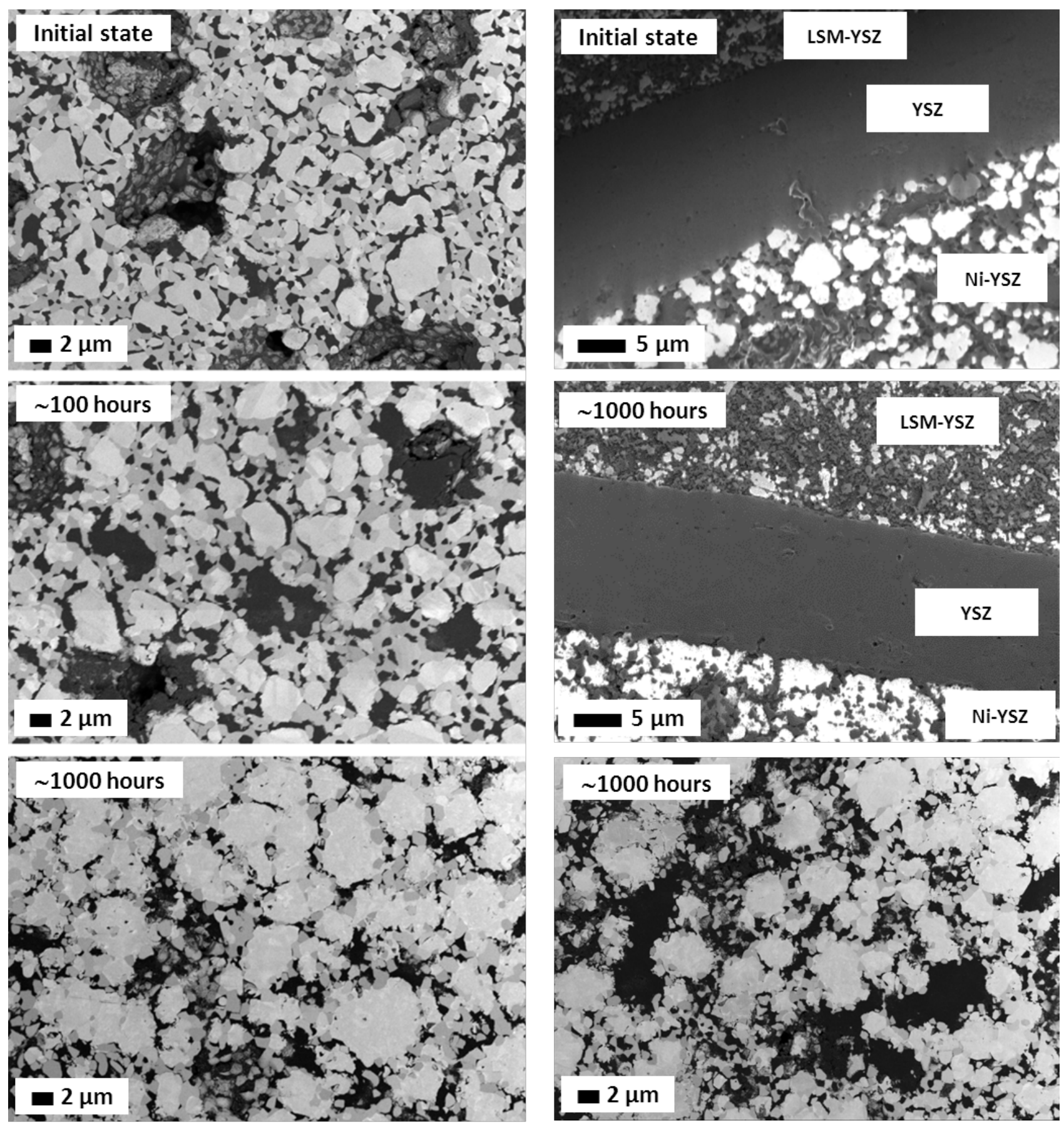


\section{References}

${ }^{1}$ R. M. Ormerod, Solid oxide fuel cells (Review), Chemical Society Reviews 32 (2003) 17-28.
${ }^{2}$ V. Lawlor, S. Griesser, G. Buchinger, A.G. Olabi, S. Cordiner, and D. Meissner, Review of the
micro-tubular solid oxide fuel cell: Part I. Stack design issues and research activities, Journal of
Power Sources 193 (2009) 387-399.
${ }^{3}$ V.M. Orera, A. Larrea and M.A. Laguna-Bercero, Fabrication methods and performance in fuel
cell and steam electrolysis operation modes of small tubular solid oxide fuel cells: a review,
Frontiers in Energy Research 2 (2014) Article 22, 1-13.
${ }^{4}$ MA Laguna-Bercero, R Campana, A Larrea, JA Kilner, VM Orera, Steam electrolysis using a
microtubular solid oxide fuel cell, Journal of The Electrochemical Society 157 (2010), B852-B855. ${ }^{5}$ A. Schuler, F. Snijkers, H.J. Schindler, U. Vogt, C. Lalanne, Cathode-supported micro-tubular SOFCs based on $\mathrm{Nd}_{1 .}{ }_{95} \mathrm{NiO}_{4}$ : Fabrication and characterisation of dip-coated electrolyte layers, Solid State Ionics 180 (2009) 805-811.

${ }^{6}$ Y. Du, N.M. Sammes, Fabrication and properties of anode-supported tubular solid oxide fuel cells, Journal of Power Sources 136 (2004) 66-71.

${ }^{7}$ H Monzón, MA Laguna-Bercero, A Larrea, BI Arias, A Várez, B Levenfeld, Design of industrially scalable microtubular solid oxide fuel cells based on an extruded support, International Journal of Hydrogen Energy 39 (10), 5470-5476.

${ }^{8}$ A. Mat, M. Canavar, B. Timurkutluk,Y. Kaplan, Investigation of micro-tube solid oxide fuel cell fabrication using extrusion method, International Journal of Hydrogen Energy (2016) in press.

${ }^{9}$ A. Faes, H. Girard, A. Zryd, Z. Wuillemin, J. Van Herle, Fabrication of structured anodesupported solid oxide fuel cell by powder injection molding, Journal of Power Sources 227 (2013) 35-40.

${ }^{10}$ D. Dong, J. Gao, X. Liu, G. Meng, Fabrication of tubular NiO/YSZ anode-support of solid oxide fuel cell by gelcasting. Journal of Power Sources 165 (2007) 217-223.

${ }^{11}$ M Morales, MA Laguna-Bercero, ME Navarro, F Espiell, M Segarra, The effect of anode support on the electrochemical performance of microtubular solid oxide fuel cells fabricated by gel-casting, RSC Advances 5 (2015), 39350-39357

12 P Sarkar, L Yamarte, H Rho, L Johanson, Anode-Supported Tubular Micro-Solid Oxide Fuel Cell, International Journal of Hydrogen Energy 4 (2007) 103-108.

${ }^{13}$ AR Hanifi, MA Laguna-Bercero, TH Etsell, P Sarkar, The effect of electrode infiltration on the performance of tubular solid oxide fuel cells under electrolysis and fuel cell modes, International Journal of Hydrogen Energy 39 (2014) 8002-8008.

${ }^{14}$ N. Droushiotis, U. Doraswami, K. Kanawka, G. H. Kelsall, K. Li, Characterization of NiO-yttria stabilized zirconia (YSZ) hollow fibres for use as SOFC anodes, Solid State Ionics 180 (2009) 1091-1099.

${ }^{15} \mathrm{~N}$. Yanga, X. Tan, Z. Ma, A phase inversion/sintering process to fabricate nickel/yttria-stabilized zirconia hollow fibers as the anode support for micro-tubular solid oxide fuel cells, Journal of Power Sources 183 (2008) 14-19. 
${ }^{16}$ K Howe, G Thompson, K Kendall, Micro-tubular solid oxide fuel cells and stacks, Journal of Power Sources 196 (2011) 1677-1686.

17 H. Sumi, T. Yamaguchi, K. Hamamoto, T. Suzuki, and Y. Fujishiro, Effects of Anode Microstructure on Mechanical and Electrochemical Properties for Anode-Supported Microtubular Solid Oxide Fuel Cells, Journal of the American Ceramic Society 96 (2013) 3584-3588.

${ }^{18}$ M. Torrell, A. Morata, P. Kayser, M. Kendall, K. Kendall, A. Tarancón, Performance and long term degradation of $7 \mathrm{~W}$ micro-tubular solid oxide fuel cells for portable applications, Journal of Power Sources 285 (2015) 439-448.

${ }^{19}$ K. Kendall, Ch. M. Dikwal and W. Bujalski, Comparative analysis of thermal and redox cycling for microtubular SOFCs, ECS Transactions 7 (2007) 1521-1526.

${ }^{20}$ H Monzón, MA Laguna-Bercero, Redox-cycling studies of anode-supported microtubular solid oxide fuel cells, International journal of hydrogen energy 37 (2012), 7262-7270.

${ }^{21}$ Y. Du, C. Finnerty, J. Jiang, Thermal stability of portable microtubular SOFCs and stacks. Journal of the Electrochemical Society 155 (2008) B972-B977.

${ }^{22}$ C. Andres Lozano, M. Ohashi, S. Shimpalee, J. W. Van Zee, and P. Aungkavattana, Comparison of Hydrogen and Methane as fuel in Micro-Tubular SOFC using Electrochemical Analysis, Journal of the Electrochemical Society 158 (2011) B1235-B1245.

${ }^{23}$ T Suzuki, T Yamaguchi, Y Fujishiro, M Awano, Current collecting efficiency of micro tubular SOFCs, Journal of Power Sources 163 (2007) 737-742.

${ }^{24}$ BI Arias-Serrano, ME Sotomayor, A Várez, B Levenfeld, H Monzón, MA Laguna-Bercero, A Larrea, High-performance Ni-YSZ thin-walled microtubes for anode-supported solid oxide fuel cells obtained by powder extrusion moulding, RSC Advances 6 (2016), 19007-19015.

${ }^{25}$ MA Laguna - Bercero, R Campana, A Larrea, JA Kilner, VM Orera, Performance and Aging of Microtubular YSZ - based Solid Oxide Regenerative Fuel Cells, Fuel Cells 11 (2011) 116-123.

${ }^{26}$ MÁ Laguna - Bercero, A Férriz, A Larrea, L Correas, VM Orera, Long - Term Stability Studies of Anode - Supported Microtubular Solid Oxide Fuel Cells, Fuel Cells 13 (2013), 1116-1122.

27 S.P.S. Badwal, K. Foger, Solid oxide electrolyte fuel cell review, Ceramics International 22 (1996) 257-265.

${ }^{28}$ S.-B. Lee, T.H. Lim, R.H. Song, D.R. Shin, S.K. Dong, Development of a 700W anodesupported micro-tubular SOFC stack for APU applications, International Journal of Hydrogen Energy, 33 (2008) 2330-2336.

${ }^{29}$ A. Momma, Y. Kaga, K. Takano, K. Nozaki, A. Negishi, K. Kato, T. Kato, T. Inagaki, H. Yoshida, K Hosoi, K. Hoshino, T. Akbay, J. Akikusa, M. Yamada, N. Chitose, AC impedance behavior of a practical-size single-cell SOFC under DC current, Solid State Ionics 174 (2004) 8795.

${ }^{30}$ E.P. Murray, T. Tsai, S.A. Barnett, Oxygen transfer processes in (La,Sr)MnO3/Y2O3-stabilized ZrO2 cathodes: an impedance spectroscopy study, Solid State Ionics 110 (1998) 235-243.

${ }^{31}$ A.C. Co, S.J. Xia, V.I. Birss, A Kinetic Study of the Oxygen Reduction Reaction at LaSrMnO3YSZ Composite Electrodes, Journal of the Electrochemical Society 152 (2005) 152 A570-A576.

${ }^{32}$ M.J. Jorgensen, M. Mogensen, Impedance of Solid Oxide Fuel Cell LSM/YSZ Composite Cathodes. Journal of the Electrochemical Society 148 (2001) A433-A442. 
${ }^{33}$ H Yokokawa, H Tu, B Iwanschitz, A Mai, Fundamental mechanisms limiting solid oxide fuel cell durability, Journal of Power Sources 182 (2008) 400-412.

${ }^{34}$ L Holzer, B Iwanschitz, T Hocker, B Münch M. Prestat, D. Wiedenmann, U. Vogt, P. Holtappels, J. Sfeir, A. Mai, Th. Graule, Microstructure degradation of cermet anodes for solid oxide fuel cells: Quantification of nickel grain growth in dry and in humid atmospheres, Journal of Power Sources 196 (2011) 1279-1294.

$35 \mathrm{H}$ Monzón, MA Laguna-Bercero, The influence of the reducing conditions on the final microstructure and performance of nickel-yttria stabilized zirconia cermets, Electrochimica Acta (2016) accepted.

${ }^{36}$ N. Christiansen, S. Primdahl, M. Wandel, S. Ramousse, A. Hagen, Status of the Solid Oxide Fuel Cell Development at Topsoe Fuel Cell A/S and DTU Energy Conversion, ECS Transactions 57 (2013) 43-52.

${ }^{37}$ A. Hagen, R. Barfod, P. Van Hendriksen, Y.-L. Liu , S. Ramousse, Degradation of Anode Supported SOFCs as a Function of Temperature and Current Load, J. Electrochem. Soc. 153 (2006) A1165-A1171.

${ }^{38}$ A Faes, A Hessler - Wyser, D Presvytes, CG Vayenas, J. Van herle, Nickel-zirconia anode degradation and triple phase boundary quantification from microstructural analysis, Fuel cells 9 (2009) 841-851.

${ }^{39}$ R.S. Gemmen, M.C. Williams, K. Gerdes, Degradation measurement and analysis for cells and stacks, Journal of Power Sources, 184 (2008) 251-259.

${ }^{40}$ K. Thyden, Y. L. Liu, J. B. Bilde-Sørensen, Microstructural characterization of SOFC Ni-YSZ anode composites, Solid State Ionics 178 (2008)1984-1989. 